\title{
EDITORIAL
}

\section{Una pizca de esperanza para tiempos inciertos}

\author{
TANia García SEDAno \\ Secretaría de redacción Femeris \\ ORCID: 0000-0003-4801-6733
}

doi: https://doi.org/10.20318/femeris.2020.5759

Resulta difícil imaginar un editorial de Femeris que no haga referencia a la situación que estamos viviendo, nos enfrentamos a la peor pandemia del último siglo.

Se trata de una situación compleja con la que tenemos que aprender a convivir, es un reto que nos compele a todos. Así, se hacen precisas medidas urgentes para que los más vulnerabilizados no se lleven la peor parte.

Quisiera hacer un sentido reconocimiento a todo el personal esencial que con su trabajo y valentía no sólo han dignificado sus profesiones y ofrecido un modelo sobre el que mirarnos si no que nos hacen deudores de una incuantificable gratitud, supeditando sus situaciones vitales al interés general y coadyuvando a que el estado social adquiera una renovada importancia. A todos los que hemos sido protagonistas de una gesta de indudable valor, confinándonos y cuidando a los demás. Y a aquéllos que han perdido la vida dejando un vacío imposible de llenar y sólo sobre llevable desde la esperanza en el fin de la epidemia.

Los efectos sociales y económicos de la pandemia son y serán devastadores, nos adentramos en una de las peores crisis de la historia y ello va a exigir lo mejor de nosotros mismos y lo mejor de nuestras sociedades.

Sin embargo, por sí solas, las medidas regionales o nacionales no resultarán suficientes para enfrentarnos a la complejidad y globalidad de esta crisis. Este momento exige políticas públicas, ambiciosas, coordinadas e innovadoras a nivel mundial junto con apoyo financiero y técnico que nos permitan vencer juntos a este desafío pues parece claro que solo podremos salir de esta si lo hacemos todos juntos.

*tgsedano@der-pu.uc3m.es 
A la sazón, se hace precisa la adopción de políticas públicas que garanticen la educación para que podamos enfrentar el desafío pendiente y evitar que seamos presas de la manipulación, la negación y podamos configurarnos como agentes clave en la reconstrucción de nuestras sociedades.

Entendemos que la perspectiva de género, subyacente también a esta realidad, requiere una especial atención, pues acrecienta los efectos de la crisis en todas las dimensiones, pero también permite que frente a centinelas de ortodoxias podamos erigirnos en garantes de valores superiores, constitucionalmente reconocidos como tales, como la igualdad y la libertad.

Desde ese prisma, el vigente número de Femeris es un tributo a todos aquellos que han perdido mucho o todo en esta situación y una ofrenda para quienes creen que el conocimiento es el camino para la reconstrucción. 